\title{
The Problems Existing in Current Enterprise Financial System Execution and Solutions
}

\author{
Meng Xuqin, Guo Hao, \\ Guo Hao, Qinhuangdao Institude of Technology, Qinhuangdao, Hebei, China, 066100
}

Keywords: Current enterprise; Financial system; Problems; Solutions

\begin{abstract}
Driven by the new situation of market economy, modern enterprises are ushered in a new development opportunity. For enterprises, financial management determines its ability to compete, so enterprise should determine a set of feasible management system according to its own actual situation to adapt to the new situation of market economy. This paper explores the problems existing in current enterprise financial system execution and the solutions.

Financial system is the most basic and the most important internal management system for enterprise survival and development. In the new situation, market economy also put forward higher request for the financial system, and the importance of financial system in enterprise is growing. In enterprise operation process, financial system is not only a code of conduct for rational handling of company's internal relationship, but also a key part of the effective division of financial responsibility and interest. But the current enterprise financial system still exist some problems in practical application, and the existence of these problems will affect the survival and development of the enterprise, so we must put forward effective solution to solve these problems.
\end{abstract}

\section{The problems existing in current enterprise financial system execution}

\section{A. There is no healthy financial system in the enterprise}

Because the current enterprise financial system does not particularly clear financial work requirements, so it cannot effectively play its functions. In addition to the unclear basic financial work responsibility, the enterprise internal supervision system is not perfect. For businesses, internal supervision system is to improve its management efficiency and the quality of financial information, and it is an important work to protect their assets. But now some financial revenues and expenditures for examination and approval in the enterprise, such as cost accounting system are not very perfect. Internal supervision work needs more attention. These caused very big effect on enterprise financial management level. Many enterprises in China have centralized leadership system, which is highly centralized operation right and ownership. This management system makes enterprises lack a certain amount of the ability to schedule money. The enterprise financial risk is bigger, and can appear a series of phenomena such as overspending, pay by the income. Decisions of enterprises in operating basically rely on the managers' feedback information and experience, and the authenticity and integrity of feedback information decide the enterprise's financial risk [1].

B. Enterprise financial management level is not high, and the mode is single

Financial management decides the survival and development of enterprises, so the important reason for further development of enterprises is that financial management level is not high and financial management modes are single. At present, some enterprises have not realized the importance of financial management, and financial management system has not been taken seriously enough. For instance: enterprise financial has no rigorous work process, and the quality of financial personnel is limited, which will directly affect the ability of enterprise financial management; Enterprise capital management system is not perfect and management also has no strict requirements, which spare part of enterprise funds, or even cause the phenomenon of bad loans; Enterprise financial concept is old with no advanced processing method, which makes enterprise financial management level is not high; Enterprise inventory management is not enough, and some products have no determined sales way, which causes serious backlog inventory 
phenomenon. In addition, the managers of enterprises value production and ignore financial management, and have not timely improvements to financial management system, and have insufficient use of resources in financial management.

\section{Financial staff lacks professional quality}

Because our country's economy system is established relatively late, a lot of managers' enterprises financial management concept cannot meet the demand of fast development time. The professional quality of financial staff also cannot meet industry's basic standard. Coupled with enterprise's not enough importance on financial management, and not very high requirement of financial personnel, enterprise's financial management is in a passive situation. The managers of enterprises lack certain knowledge of financial management and lack of evaluation and supervision system for financial management. Because most of the enterprises have centralized leadership system, if managers have no professional knowledge of financial management, they cannot formulate effective way of enterprise operation according to the actual financial situation. The professional quality of financial personnel can't meet the requirements of modern enterprise financial management informationization. To a large extent, it will affect the manager's decision, and will affect the survival and development of the enterprise [2].

$D$. There is less accounting content in enterprise financial system, and accounting information lacks authenticity

Accounting work promotes the enterprise's survival and development, but the current financial system involves less accounting content, only made relevant provisions on the contents of financial management and this will cause lacking the authenticity of accounting information. Although many companies have adopted computerized accounting, but manual accounting is widely applied in enterprise financial work, which will not only cause low and slow efficiency of charge account, still it can make enterprise's accounting records have no clear specification, more casual, leading to the enterprise asset accounts not tally with the actual. False accounting information has a great negative impact on management and development of the enterprise.

\section{$E$. The existence of planned economy restricts the independent financial of enterprises}

Chinese market economic system was set up late. Under the influence of planned economy, the active enthusiasm and initiative of enterprises have certain restrictions. The influences of planned economy on the enterprise are mainly in the following four aspects [3]:

(1) Cost project of the enterprise is fixed by the state, such as: some industrial enterprise's product cost project is divided into material, artificial, and expenses, etc., rather than according to the enterprise's management mode and its own operating characteristics.

(2) Enterprises inherent assets depreciation policy, standards and so on are formulated by national unity according to the inherent degree of wear and tear of the asset, rather than based on the operating characteristics of the enterprise itself to determine the survival of its inherent assets.

(3) Bad debt is not determined according to the specific internal financial situation, but according to certain proportion of the national late charge account.

(4) Enterprise worker's treatment has also unified regulations of the state, but in the new situation of market economy, worker's pay should be decided by the enterprises themselves, rather than determined by the national unity, because different enterprises have their own characteristics.

\section{The solution of the problems existing in current enterprise financial system execution}

\section{A. Improve enterprise's financial system, and strengthen financial supervision}

For enterprises, the effective premise of financial management quality improving is to have a sound financial system. Financial system is the important basis of enterprise survival and development, and financial regulation in financial system can effectively guarantee the integrity and authenticity of the enterprise data, and have certain specifications for enterprise behavior. But now, enterprise's financial system is not perfect. To some extent, it will hinder the development of 
enterprise and progress, therefore, improve enterprise's financial system and strengthen financial supervision are the top issues facing.

To improve the work of enterprise financial system, enterprises should first change the concept of financial management and internal regulation, attach importance to financial management, and have relevant staff training on a regular basis to improve their professional skills, and then enhance the consciousness of financial regulation. Next, perfect the financial system, increase the intensity of enterprise financial regulation, and seriously deal with the phenomenon of laws and regulations violation according to the laws and regulations of financial management in the process to form a powerful financial regulatory system. Then, establish internal financial supervision system, and formulate feasible and detailed work process, and regulate strictly in accordance with the relevant rules and regulations. The last thing is personnel supervision. Put the record and management of financial work to multiple personnel processing in forming a state of mutual supervision.

\section{$B$. Strengthen financial management, and carry out informatization management mode}

Strengthening financial management is an important approach to improve the competitiveness of enterprises, which can make the enterprise funds fully effective, improve enterprise financial management level, and protect the safety of enterprise assets. To strengthen the financial management, the first step is to standardize financial management system work, and enterprise asset management and recording work should be separated, namely personnel records, personnel management, to ensure that financial management system won't appear any flaws in the practice. The second step is the increasing effectiveness of the use of funds. Make money balance of payments; for example, do not use short-term borrowing to buy some fixed assets in avoiding emergency capital turnover difficult phenomenon. Step three is to accurately predict money pay and back, namely to have a certain understanding and grasp of account recoup to avoid the imbalances.

In the new situation of market economy, single financial management pattern already cannot satisfy the survival and development of the enterprise. In order to adapt to the informationization and internationalization of the market economy, enterprise should carry out informatization management mode to promote the development of financial management work and improve enterprise development speed [4].

\section{Improve professional staff quality, and strengthen financial management work}

In order to adapt to the development of market economy and the needs of enterprises, financial management personnel's professional quality should be improved, and the development basis of the enterprise is good human resources. Because accounting knowledge updates faster, enterprise can have regular training and examination for financial staff to optimize financial management personnel agency. Only in this way can constantly professional training of financial personnel more effectively improve the professional quality of staff, and make enterprise financial management more adapt to the new situation of market economy. Financial staff's professional skills and business level improvement and financial management strengthening work can make enterprise's survival and development.

\section{Standardize financial system, and clear financial system objection}

In current enterprise financial system, accounting content involves less, which makes the lacking authenticity of accounting information. Current enterprise financial system should be effectively reformed, improved and standardized. When standardizing financial system, according to the actual situation of enterprises and the demand of market and enterprises, determine the specific behavior of financial system. Because companies should have a certain amount of time to adapt to the practice of the new system, gradually improve and develop financial system after the reform in order to better adapt to the new situation of market economy. In standard enterprise financial management system, clear target of financial system. According to the actual situation of enterprises, determine the specific goal of financial management, and according to the goal of financial management, clear enterprise's development direction. Because companies operating environment is constantly changing, financial management department should determine the feasible right management way according to their own actual situation and financial system target 
[5].

E. Get rid of the planned economy, and enhances enterprise active power

Under the influence of planned economy, enterprise is facing problems under current enterprise financial system. It can be seen that enterprises should get rid of the influence of planned economy, and strengthen financial autonomy.

(1) Enterprise should change project cost rules. After determining the scope of the cost, according to their own mode of operation and characteristics, decide cost projects.

(2) Enterprises determine inherent assets depreciation policy according to their specific circumstances, rather than by the unified regulations of the state, which is advantageous to enterprise active autonomy.

(3) Enterprises change provisions for impairment. Make relevant provisions for the rights and interests of impairment after specification management behavior.

(4) Enterprises determine independently worker's treatment. Rewards and punishment system are set by the enterprise according to the characteristics of relevant rules and regulations.

\section{Conclusion}

Current enterprise financial system has some problems in implementation process, which are bad for enterprise's operation. To solve these problems, some solutions are put forward, and these methods require enterprises decision according to their own actual situation. Starting from the actual situation of them, establish and perfect the financial system and strengthen financial supervision. A clear system of function realizes the goal to be effective financial management itself, and promote enterprise's survival and development.

\section{References}

[1] Sheng Xiaoli. Situation analysis of current small and medium-sized enterprise financial system [J]. Journal of Chinese Market, 2015, (6) : 25-26.

[2] Zhang Hui. Enterprise financial management problems and solutions [J]. China's Collective Economy, 2015, (13) : 112-113.

[3] Feng Zhilei. Enterprise financial management system and problem study [J]. Chinese and Foreign Entrepreneurs, 2013, (27) : 169-170.

[4] Zhang Wei. Existing problems and countermeasures of enterprise financial system selection [J]. Journal of Traffic Accounting, 2012, (7) : 88-90.

[5] Zhang Jun, Sun Hongyan. Thoughts on the present situation and problems of enterprise financial system [J]. Journal of Management, 2013, (27) : 189. 